\title{
A MECANIZAÇÃO DA IMPRENSA ATRAVÉS DOS SEMANÁRIOS PAULISTANOS DE NARRATIVA IRREVERENTE (1900-1911)*
}

\author{
Paula Janovitch \\ Doutora em História -FFLCH/USP
}

\section{Resumo}

Este artigo procura analisar a forma singular com que a narrativa humorística dos pequenos semanários paulistanos representou a presença da mecanização da imprensa no início do século XX, momento em que esta tornava-se um dos principais veículos de comunicação de massa.

\section{Abstract}

This article attempts to analyse in a singular manner in what way the humoristic narrative of the São Paulo small weekly publications represents the presence of the mechanization of the newspapers at the beginning of the 20 th century, a moment when the press became one of the principal mass communication.

\section{Pallavras-Chave}

Belle Époque em São Paulo • Cultura Urbana • Imprensa Humorística • História da Caricatura

\section{Keywords}

Belle Époque in São Paulo • Urban Culture • Humorous Press • History of Caricature

\footnotetext{
* Artigo baseado em estudo mais amplo: Preso por Trocadilho: a imprensa de narrativa irreverente paulistana de 1900 a 1911. São Paulo, FFLCH/USP, 2003 (Tese de doutorado).
} 
A mecanização dos meios de comunicação e da impressão foi de fundamental importância para a expansão da imprensa no início do século XX. Os novos prelos utilizados pela grande imprensa eram comemorados em pequenos comentários dos semanários de narrativa irreverente paulistana. Surgiam as Marionis e outras tantas marcas de prelos capazes de multiplicar os exemplares e combinar textos e imagens como ao longo do século XIX nunca havia sido possível. Aliados à maior capacidade de produção, impressão e composição, estavam os correios e telégrafos, principais responsáveis pela distribuição dos jornais, assim como meio de comunicação fundamental para que leitores e os próprios produtores de jornais mantivessem contato com os acontecimentos do momento ${ }^{1}$.

Apesar da péssima fama dos correios por suas constantes falhas e extravios de mensagens que atravessou o século XIX, e permaneceu ao longo da primeira década do século XX em pequenas notas e comentários críticos dos semanários de narrativa irreverente, era através deste veículo de comunicação de duvidosa eficácia que se faziam entregas em locais distantes do interior paulista, recebiam-se jornais de várias partes do mundo e correspondências de leitores e colaboradores das folhas.

Pelos correios e telégrafos as notícias ampliavam os assuntos das folhas irreverentes do começo do século XX. Até mesmo nomes de jornais e chamadas de texto passam a dialogar com a imediaticidade que estes meios de comunicação e expressão sugeriam. Chamadas com o título de "Ultima hora", "O Momento Político", clichês e pequenas matérias com legendas-título "Nossos Instantâneos" ou a remissão literal aos "telegramas" compartilhavam lugar com colunas cada vez mais fixas de cartas, correspondências, postas restantes (caixas postais), telegramas e instantâneos que, em formatos e estilos diversos, dialogavam de maneira bastante singular com as transformações da imprensa via mecanização das palavras.

\footnotetext{
${ }^{1}$ Sobre a modernização da imprensa no Brasil, ver Gordinho (1991), "O Começo da Modernidade", em que a autora destaca a presença de máquinas tipográficas mais antigas, utilizadas na maior parte pelos pequenos semanários, e as grandes máquinas, em menor quantidade, apenas nos grandes diários como $O$ Estado de São Paulo. Sobre o mesmo assunto, ver também Martins (2001) em capítulo "A Oficina das Palavras", em que a autora faz vários comentários sobre a presença da tipografia voltada para a produção das revistas no início do século XX.
} 
Muitos anos antes que os pequenos semanários de narrativa irreverente do começo do século XX começassem a colocar em seus cabeçalhos de primeira folha endereços de redação, oficinas e valores de assinatura, a antiga tradição da imprensa do final do século XIX registrava em todos eles talvez um único ponto fixo entre as variáveis que atingiam a curta história da maioria naquele momento. O ponto de contato destes pequenos jornais era sua posta restante: um dos únicos elos de comunicação das folhas com seus leitores, colaboradores e demais interessados. Deste lugar histórico de contato e recebimento de mensagens, a posta restante transformouse na porta de entrada da imprensa, coluna fixa freqüente na maioria dos semanários paulistanos do início do século XX.

Estas colunas de nomes diversos, todos derivados da matriz posta restante, veiculavam na forma de matérias-mensagem normalmente curtas o que os jornais supostamente haviam recebido em primeira mão pelos correios, fossem estes recebimentos ficcionais ou de fato reais. A partir do registro de sua entrada, sucediam-se os comentários críticos do jornal que poderiam incluir, excluir ou apenas agradecer as mensagens recebidas.

Sem detalhar por hora o conteúdo desta coluna de entrada de mensagens, o que gostaria de destacar aqui é o papel fundamental da posta restante como um dos importantes elos de ligação entre a mecanização da imprensa e a incorporação desta mecânica no próprio corpo das folhas irreverentes.

Da mesma maneira que a posta restante foi incorporada nas folhas em locais fixos, o mesmo ocorria em relação ao material veiculado através dos correios, as correspondências, que na forma de colunas assumiam o estilo epistolar de cartas e bilhetes. A princípio nada mais do que metáforas e alusões aos serviços postais presentes na distribuição e motivos de criação das matérias irreverentes.

Parte dessas alusões e metáforas presentes nos pequenos semanários pode ser compreendida de fato pela importância dos meios de comunicação na história da imprensa. Principalmente em sua pertinência ao jornalismo no começo do século XX, momento em que este passou a se afirmar com um grande veículo de comunicação de massa.

Porém, a convivência entre os correios e a imprensa é bem mais antiga. Poderiase mesmo dizer que esta passou a ter características de periódico a partir do momento em que os serviços postais adquiriram maior regularidade. Rizzini aponta o século XVII como o momento em que na França passaram a se fixar postas em várias cidades do interior (Rizzini 1968:60). 
Através das postas fixas, as correspondências, ou cartas particulares que tratavam das novidades ocorridas em Paris ou demais cidades ligadas pelos correios, passaram a veicular com mais constância as narrativas epistolares que pela mudança de periodicidade também adquiriam um estilo singular na forma de comentar os acontecimentos do momento.

Estas cartas constituíam-se quase como crônicas da semana. A partir do momento em que o correio passou a se fixar nas pequenas cidades dos arredores de Paris por meio das postas, estas narrativas epistolares começaram a ser recebidas em intervalos de tempo previsíveis, de mais ou menos oito dias. Talvez desta regularidade temporal, originou-se a frequiência semanária da imprensa que marcou a maioria da distribuição dos periódicos até o final do século XIX, momento em que tomava força os grandes jornais diários. A frequiência mínima de uma semana ao longo do século XX permaneceu ditando o aparecimento da maioria dos pequenos semanários, revistas de variedades, ilustradas, humorísticas ou mesmo de atualidades. (Rizzini 1968:60)

O estilo epistolar com teor de atualidades, desenvolvido nessas primeiras correspondências, também foi o começo da carreira de muitos escritores ilustres. A confecção das cartas trocadas em sua maioria entre pessoas de um mesmo círculo social era dinamizada pelos comentários a fatos ocorridos ao longo da semana nos locais de divertimento, na vida íntima ou mesmo em palestras sobre questões políticas e econômicas em voga naquele momento.

O interesse despertado pelo estilo epistolar tornara-se uma forma tão difundida nos circuitos dos salões que as cartas enviadas a um único remetente passaram a ser divulgadas para vários receptores, sendo comumente lidas em voz alta e depois lembradas pelos ouvintes por um longo período de tempo. É exemplar o caso de Mlle. Scudéry que, em seu livro Les Conversations Nouvelles, incluiu um capítulo sobre a forma de se escrever as cartas de novidades. Esta mesma senhora não ia à casa de Mme. de La Fayette sem levar as últimas cartas de sua filha, suas cartas de nouvelles (Rizzini 1968:65), as quais causavam tanta sensação nos ouvintes. Muitos escritores como Aretino, a própria Madame de Sevigné ou Voltaire, depois do enorme sucesso que obtiveram com suas correspondências, acabaram por reuni-las e publicálas no formato de livro.

Além da formação de um estilo narrativo epistolar e de atualidades oriundo das mensagens veiculadas através da fixação dos correios, esse veículo de comunicação destacou-se historicamente na imprensa como a forma primária de como os jornais 
passariam a ser distribuídos para um grande público. Portanto, sem os serviços postais a imprensa como a compreendemos hoje, um órgão de comunicação de massa, estaria fadado ao fracasso.

Já a distribuição dos jornais na rua e sua venda avulsa, ao contrário do que podemos imaginar, foram conquistas recentes. Havia gazetas manuscritas em Paris no século XVII e existiam lugares fixos para se ler as notícias. A árvore de Cracóvia foi uma destas famosas "bolsas de noticias de Paris". Outros pontos permanentes, onde estas folhas poderiam ser encontradas, foram os salões, cafés, praças e pontes da cidade, lugares em que jornais eram fixados e muitas vezes lidos em voz alta para uma grande maioria de analfabetos que habitava a cidade de Paris ${ }^{2}$.

Poucas pessoas tinham condições de comprar as folhas, e quando as adquiriam, utilizavam assinaturas que eram enviadas através dos correios. A venda avulsa praticamente não existia. Para a vida noticiosa, a concepção de rua como lugar de distribuição da notícia surgiu somente no final do século XIX. A rua até então era um dos lugares de maior vigilância policial das grandes cidades européias como a já citada cidade de Paris e a conturbada Londres. Nelas os policiais se aprimoravam em perseguir gazeteiros, chegando a levantar entre a população que frequientava as ruas falsos suspeitos como barbeiros e lavadeiras, ou ainda aqueles taxados previamente pela polícia como "desocupados" em geral".

O uso dos pseudônimos ou de textos anônimos também buscava preservar a curta vida dos jornais e a integridade de seus colaboradores. Dificilmente temos registros de nomes de colaboradores que deixaram suas contribuições nas gazetas (Rizzini 1968:63).

A alternativa de sobrevivência que restava a esses tablóides manuscritos foi ficar longe das ruas através da venda de assinaturas prévias. Dessa maneira, os jornais estavam restritos por um longo período de tempo a um número de assinantes-leitores e a alguns pontos fixos nas grandes cidades.

\footnotetext{
${ }^{2}$ Sobre a presença da imprensa na vida cultural parisiense no século XIX, ver Weber (1998) e também Ortiz (1991).

${ }^{3}$ Interessante notar que nos Relatórios da Secretaria de Justiça e Segurança Pública de São Paulo do início do século XX, entre as várias apreensões feitas nas ruas da cidade na categoria profissões/prisão, a maioria são registros de "desocupados", "vagabundos" e jornaleiros, demonstrando que nessa época as ruas em São Paulo ainda eram um lugar perigoso para a imprensa.
} 
No Brasil, a imprensa só veio a conquistar as ruas, a venda avulsa, no início do século XX.Ao longo de todo o século anterior sua venda estava vinculada a postos fixos localizados em livrarias ou nas próprias oficinas e redações dos poucos jornais. (Sodré 1998:226).

Em São Paulo, ao longo do século XIX, assinantes que morassem fora da cidade eram extremamente raros. Quando havia necessidade, a distribuição para lugares distantes, tinha que ser feita pelos correios que à época se associavam aos limitados serviços ferroviários, animais de carga como os burros ou aos homens a pé, também conhecidos por pedestres.

O funcionamento precário das redes de comunicação entre a capital paulista e as cidades do interior tornava o serviço de entregas numa forma pouco confiável de envio dos exemplares aos distantes assinantes-leitores. Provavelmente esses raros assinantes recebiam esporadicamente seus exemplares, o que resultava em inúmeras reclamações por parte dos jornais e dos próprios leitores que muitas vezes deixavam de assinar as folhas pelos constantes extravios.

Anúncios e comentários, apanhados no pequeno semanário ilustrado e humorístico paulistano O Cabrião (1867) em meados do século XIX, já atestam de forma bem clara as falhas dos correios na entrega dos jornais. Os comentários sugeriam extravios de correspondência e uma certa incompetência por parte dos funcionários dos correios:

O "Cabrião" não póde conservar-se silencioso, como quizera á respeito do modo porque é feito o serviço postal. Por maior pontualidade que haja na remessa do jornal, chovem as reclamações de muitos pontos, especialmente de Cunha, Sorocaba e Una. A cousa assim não vai bem. É certo que ha por ahi muito agente relachado, mas para tudo ha remédio (O Cabrião, 10 fev. 1867).

As reclamações quanto à má distribuição também surgiam nas notas da imprensa de narrativa irreverente, justificada pelas longas distâncias e ausência de linhas férreas e postas restantes que restringiam ainda mais a periodicidade dos jornais paulista ao longo do século XIX. Talvez este seja um dos motivos do forte caráter regionalista da imprensa no Brasil e, particularmente em São Paulo, tenha como fundamento a deficitária rede de transportes que deixou por um longo período de tempo as grandes cidades do país "isoladas" das outras regiões.

Em 1867, enquanto se inaugurava, em Campinas, o primeiro locomóvel a vapor o da fábrica de chapéus dos irmãos Bierrenback - estabelecia-se o correio diário 
em carros entre essa cidade e a capital da província. Entre São Paulo e a Corte, ainda em 1873, a correspondência era levada por navios da Companhia de Navegação Paulista, de cinco em cinco dias. Mas nesta altura, entre Santos, S. Paulo, Jundiaí, Campinas e Itu, era transportada por ferrovias e, portanto, diária, o que dava à imprensa paulistana possibilidades novas de distribuição (Sodré 1998:208).

Na virada do século XIX para o XX, os serviços postais já haviam aberto mais de 75 agências postais no interior paulista, porém os transtornos quanto à entrega e à eficiência de seus serviços continuavam a ser motivos para as matérias dos jornais irreverentes ao longo de toda a primeira década do século XX.

\author{
"Com o 'Correio"” \\ É a terceira vez que o desmazelado serviço postal, pela já célebre Repartição do \\ Correio, nos devolve jornaes, muitas vezes sem procurar o destinatario. O Dr. \\ Gomes Cardim que tem caixa sob n. 809, reclama a falta da nossa revista. \\ Porque? \\ Porque o carteiro naturalmente em concluios hermistas, deixa a sua obrigação, \\ pela politiquice do rebenque. \\ Demais a mais o Dr. Gomes Cardim já uma vez pedia que sua correspondencia \\ fosse collocada na caixa. \\ Qual a razão dessa falta de escrupulo e attenção? \\ Só o correio o sabe. \\ (O Pirralho, 23 dez. 1911) ${ }^{4}$
}

\footnotetext{
${ }^{4}$ Apesar de não se incluir de forma direta no tema tratado aqui, penso ser importante apontar que nesta pequena nota d'O Pirralho (1911) a narrativa irreverente se apropriava das questões críticas já tratadas em $O$ Cabrião (1867) de maneira totalmente diversa deste primeiro jornal. $O$ Pirralho, ao representar as falhas do correio, ia além da crítica direta às questões técnicas, usando-as muitas vezes apenas como motivo para experimentar novas formas de expressão da linguagem: diálogos diretos misturados a piadas ligadas ao clima político de disputa entre hermistas e civilistas encabeçada por personagem vítima das falhas do correio e oriundo da própria vida cultural paulistana - Gomes Cardim. Ver em citação no livro de Sodré, uma outra pilhéria crítica envolvendo o nome de Gomes Cardim publicada na Platéa em 4 de dezembro de 1893 que, com tema diverso porém de intenção bem próxima da pilhéria feita por $O$ Pirralho se dava a nota de que o "colega Gomes Cardim" fora levado pela polícia por estar lendo no bonde o livro de Eduardo Prado de oposição feroz a República, A Ilusão Americana (1893). (Sodré: 1998: 263).
} 
A fixação de um número maior de postas restantes pelo interior paulista, apesar da precariedade dos serviços do correio na primeira década do século XX, significava um aumento substantivo do número de assinantes-leitores. Ao mesmo tempo a possibilidade de comunicação entre cidades até então inacessíveis acabava por ampliar a geografia temática das próprias folhas que tornavam o interior paulista "conhecido" em suas matérias e ilustrações, até pouco tempo definido nas legendas dos mapas apenas pelo termo genérico de "terrenos desconhecidos",

Através das colaborações, anúncios publicitários, deslocamento de repórteres ficcionais ou reais, estas cidades do interior passavam a participar da vida dos vários semanários de narrativa irreverente paulistanos. Pelas postas restantes migravam para dentro das matérias e ilustrações desses periódicos as mais variadas correspondências entre poetas, escritores, colaborados esporádicos, ilustradores, fatos diversos ou mesmo os imigrantes, principalmente os de origem italiana dirigindose à capital paulista.

Da diversidade de pessoas, hábitos em deslocamentos geográficos, a narrativa irreverente e noticiosa representava o trânsito de linguagens e perfis humanos presentes nas transformações da paisagem urbana da cidade. Os tipos urbanos, duplas de calungas em diálogos desencontrados nas ruas, cartas dialetais de linguagem já estilizada do que era apanhado sonoramente pela cidade e, acelerando mais os tempos, as mensagens em estilo telegráfico, curtas, rápidas e muito pouco diretas.

Aliados modernos na distribuição e confecção das correspondências epistolares, surgiam para a imprensa os telegramas. Mais rápidos e em notas mais curtas do que as correspondências, as mensagens telegráficas, sem tantos vínculos históricos com a imprensa, despontavam nas colunas dos jornais paulistanos desde o final do século XIX, momento em que começaram a se implantar os primeiros telégrafos no Brasil.

No início do século XX, ainda no formato de colunas fixas dos semanários, os telegramas passavam a ser incorporados pela narrativa irreverente, justamente por

\footnotetext{
5 "Os terrenos desconhecidos" eram registrados nas legendas do mapa do Estado de São Paulo como áreas que ainda não haviam sido reconhecidas oficialmente. No livro de Redondo (1912: 25), em uma de suas crônica, "O Phonográpho", o protagonista Julião "vive numa zona remota de S.Paulo que no mappa ainda figura, neste adeantado começo de século XX, com a legenda significativa e pouco edificante de terrenos desconhecidos".
} 
conta de seus atributos peculiares, a mensagem sintética, às vezes quase incompreensível pela quantidade de palavras abreviadas, sinais cifrados, e sua capacidade de informação imediata. De suas características estruturais presentes nas colunas fixas das folhas, ampliavam-se suas possibilidades lúdicas e colocavam sobre a brevidade das mensagens a confusão dos mesmos tempos (Maciel 1998) ${ }^{6}$.

\section{0 lugar das " postas restantes" nos pequenos semanários de narrativa irreverente}

José Agudo, em seu livro Cartas D’Oeste (1914), inicia sua narrativa com a descrição de um tipo bem urbano da cidade de São Paulo, Juvenal Paulista. Este personagem caracterizava-se por ser um sujeito que pouco saía da cidade de São Paulo, fora algumas escapadas para Santos ou Rio de Janeiro. De resto o tal Juvenal não "arredava” pé do Triângulo central da cidade de São Paulo. Ninguém sabia onde ele morava, mas as pessoas que o conheciam sabiam que era em São Paulo e que tinha uma caixa no correio, "apezar da distribuição postal ser cada vez mais passível de melhoras, que sempre vão ficando adiadas para as calendas gregas” (Agudo 1914:6).

Juvenal Paulista, personagem tipo urbano de São Paulo, sem lugar registrado de moradia, porém com caixa postal determinada, talvez seja uma representação bastante interessante do caráter das folhas de narrativa irreverente que, como ele, restringiam-se a dar como sua única referência fixa a posta restante (caixa postal). Pouco ou nada se sabia dos endereços das redações e oficinas dos pequenos jornalecos dos primeiros anos do século XX.

Como as colunas das folhas, as postas restantes ocupavam um lugar fixo na maior parte dos jornais de narrativa irreverente de São Paulo entre 1900 e 1911. Apareciam com vários sinônimos: no semanário italiano La Birichina (1902), "Piccola Posta", no Nova Cruzada (1904), "Nossa Carteira" ou, de forma mais literal, "Posta Restante", no Cri-Cri (1907), "Correio sem Sel-o", seguido de uma chamada-título maior de "Cartas Multadas", em A Ronda (1908), "Mochila de Papeis", em O Bicho (1909), “Carteira do Bicho" e em O Pirralho(1911), o "Pirralho Carteiro".

\footnotetext{
${ }^{6} \mathrm{Na}$ interessante pesquisa de Maciel (1998) a autora atenta para o fato que no início as mensagens telegráficas brasileiras produziram uma enorme quantidade de confusões entre aqueles que enviam os telegramas e os que recebiam. Ambos, muitas vezes, não dominavam os códigos telegráficos. $\mathrm{O}$ fato provavelmente gerou um anedotário grande nos semanários de narrativa irreverente do início do século XX.
} 


\section{0 que chegava nas "postas restantes" dos semanários de narrativa irreverente?}

Poderia dizer-se que quase tudo em forma de miscelânea. Leitores que enviavam colaborações como a de "Domenico Torre - Votra poesia aud à prossima numero" (La Birichina, 4 set. 1902), de jornais do Rio de Janeiro, de São Paulo, de outras capitais do País ou mesmo de distantes cidades do interior: "Recebemos e agradecemos: O brilhante diário de Benjamin Motta ${ }^{7}$ e de $\mathrm{P}$ de Ambrys, A Tribuna de Jacarey. - A República de Itú - O Jornal da Tarde. - O soberbo último número da Vida Paulista - O Correio de Amparo" (Nova Cruzada, $1^{\circ}$ jan. 1904).

Pequenos bilhetes e mensagens de redatores e ilustradores participantes da confecção dos jornais, os quais, por vezes, adicionavam suas pilhérias às pequenas notas enviadas às "caixas": "Bicho-mór - Nem se discute. Acceitar a sua colaboração equivale a contar com mais um forte elemento para sustentar a nota do Bicho. $\underline{\mathrm{A}}$ casa é sua [grifo meu]" (O Bicho, 4 set. 1909).

Ao se fixarem como colunas dos jornais irreverentes, as "postas restantes" aproveitavam ao máximo as características mais aparentes das caixas postais do correio, porém se distanciavam de sua mecânica real ao subverterem esses motivos primários através do conteúdo e do estilo em que viriam as enigmáticas mensagens tramadas na maioria das vezes na redação dos próprios semanários.

Dessa proximidade com a redação dos jornais, as colunas de "postas restantes" dos pequenos semanários também proporcionavam um ar de intimidade que quase cheirava a "cozinha" dos "bastidores da notícia". O formato da coluna, construído em mensagens curtas, repletas de pseudônimos e frases entrecortadas, parecia colocar o leitor em contato com uma conversa já começada há muito tempo. Essa estrutura de mensagens cifradas logo à entrada dos jornais também servia de chamadas rápidas a possíveis colaborações e colaboradores que apareceriam em outras seções dos semanários: "Sr. Jua-Capital - Recebemos e muito de coração agradecemos os esplendidos desenhos que offereceu á RONDA. $\underline{\mathrm{O} \text { cabeçalho esta de primeira ordem e havemos }}$ de inagural-o em setembro próximo [grifo meu]" (A Ronda, 27 ago. 1908).

\footnotetext{
${ }^{7}$ Personagem da vida literária que teve suas obras criticadas em vários jornais irreverentes do período.
} 
A maneira pela qual nas "postas restantes" os redatores dirigiam-se ao público leitor, supostamente aquele que enviara a colaboração ou a mensagem, também era expressa em estilo bastante singular. Além do registro freqüente de cordiais agradecimentos às colaborações recebidas ao longo da semana, seguiam-se comentários críticos, por vezes de "dura" pilhéria ao material remetido à redação.

Um apreciador da Ronda - Capital - Agradecemos os seus parabéns, porque são sinceros, mas recusamos os seus versos, porque são quebrados. Vejá lá si isto tem geito de verso, meu camarada:

"Vendo um enterro que passava,

Zé-Bedeu de Faria Porto

A um padre que perto estava

Perguntou quem era o morto.

Diz o padre aixando assumpto

Para dar á troça expreção:

O morto é aquelle defunto

Que vai dentro do caixão".

Aquele padre, aixando assumpto, está de lhe tirar o chapéo. O amigo não aixa? [grifo meu] (A Ronda, 13 ago. 1908)

O escritor Cornélio Pires, em entrevista dada a Silveira Peixoto, comentava passagem bastante semelhante a esta encontrada nas colunas de "posta restante" de $A$ Ronda. O poeta humorístico, ao ser inquirido sobre o início de sua carreira como escritor, contava a Peixoto que começara sua carreira enviando um curto soneto para um pequeno jornal da sua cidade, Tietê, que logo foi publicado. "Por que será, querida minha Alice, que quanto mais procuro te deixar, mais, no teu rosto, estampa-se a meiguice, para melhor, assim, me cativar?" (Peixoto 1940:210)

Porém, ainda dizia o conhecido escritor humorístico, a alegria de ver seu primeiro trabalho publicado logo foi suspensa por uma carta enviada à sua casa parodiando seu soneto: "Por que será, Cornélio, amigo meu, que quanto mais procuro te querer, mais te afiguras tipo de sandeu, para melhor, assim, me aborrecer?" (Peixoto 1940:210)

Confessava o autor que os tais versos paródicos o deixaram por alguns dias um pouco amargurado, mas o ocorrido não o intimidou a criar outros tantos sonetos, o que veio a fazer logo em seguida. Afirmava Pires que a crítica feita aos seus primeiros versos aprofundou muito mais o gênero singular de que dizia ter sido inventor - "os sonetos caipiras". 
Nos versos que se seguiram a esta primeira contribuição do autor, o efeito duplo da crítica já poderia ser notado. Ainda nos seus comentários, dizia ele que "o feitiço havia virado contra o feiticeiro". Pois os tais "sonetos caipiras" inventados acabaram por fazer enorme sucesso ao entrarem sem querer, pelas mãos de um amigo que queria lhe fazer troça, na "posta restante" de uma revista carioca famosa à época. Da crítica ao primeiro soneto enviado para o jornal de Tietê, fora o autor sucedido pela surpresa e boa acolhida da segunda publicação entrada pela "posta” do Malho (Peixoto 1940:211).

Um dia, vieram perguntar-me si já vira o "Almanaque do Malho". Respondi que não. "Trás quatro sonetos de você, em pagina especial" - disseram-me. Sai correndo, fui à livraria da cidade e pedi o tal almanaque... Lá estavam os meus versos! Foi um deslumbramento! E dessa vez, não recebi qualquer parodia (Peixoto 1940:211).

Destes primeiros sonetos de Cornélio Pires enviados para os jornais nasciam outras tantas criações do autor que se tornaram freqüentes nos semanários de narrativa humorística paulistanos do início do século XX. Destacavam-se entre eles as famosas colunas de correspondências epistolares caipiras que provavelmente foram, em sua maior parte, escritas por Cornélio Pires, "o inventor do soneto caipira" ".

As "postas restantes" eram como portas de entrada dos semanários e assumiam uma abordagem bastante interessante, como as notas críticas das folhas irreverentes. Ao mesmo tempo que eram "duras" nos comentários às mensagens, dando-se liberdades de rabiscar sobre o suposto material enviado pelos colaboradores, esta crítica tornava-se logo leve e íntima do suposto receptor e para o próprio leitor. Por um tipo de mecanismo de dupla entrada, esta crítica irreverente nunca matava o seu motivo primário de "troça", apenas destacava suas linhas mais agudas e multiplicava as possibilidades do assunto, mesmo que esta, na maioria das vezes, viesse a público através do crivo crítico bem-sucedido de colunas das "Cartas" já "Multadas".

\footnotetext{
${ }^{8}$ Cornélio Pires provavelmente escrevia as colunas de correspondências caipiras registradas na revista A Farpa (1910), “Cartas Matutinas", com pseudônimo de Bastion e em O Pirralho (1911) "Correspondência da Xiririca", como Fidêncio da Costa. Em ambos há indícios claros de sua participação e colaboração. Sobre Cornélio Pires ver Dantas (1976:57) e Saliba (2002: 157), em que o autor oferece ao leitor um quadro de humoristas paulistas da belle époque.
} 
Correio sem sel-o

"Cartas multadas"

Pedro C. - Aguarde ocasião e não perca a Ilusão...

Lálá - Ca veio ter o seu Desengano. Não direi que se desengane de ser poeta, porque nutro sólidas esperanças de vel-o ainda hombrear com Bilac e outros daqui a cinconeta annos. Com tudo acho melhor dedicar-se ao lapis e deixar a lyra si et in quantum...

A. L. - Obrigado pelos elogios. Mal recompensado não devia o amigo chamar ao soneto que me envia, mas o precioso tempo que nelle perdeu. N. Nobre.

(Cri-Cri, 1907, n. 19)

As "postas restantes", como também aponta o depoimento de Cornélio Pires, serviam como entrada de brincadeiras, desafios literários e ilustrados, para um circuito fechado de redatores, jornalistas ou pessoas ligadas a vida cultural. Seu teor de intimidade sugerida nas mensagens-comentário por vezes vinha acompanhado de apelidos, pseudônimos que indicavam esta circulação da matéria que ainda considerada "prima" já se fazia pilhéria crítica e recriação literária.

Tanto Rubem do Amaral como Monteiro Lobato, que além de livros publicados colaboraram nas revistas e jornais da época, comentavam suas primeiras matérias na imprensa. Amaral acentuava o prazer que tinha em inventar pseudônimos dos mais diversos a fim de "farpear" melhor com suas "vítimas"(Peixoto 1940:189), e Lobato adicionava ao prazer da invenção dos inúmeros pseudônimos a liberdade de escrever de forma crítica para esta pequena imprensa: em ritmo de "desabafos", "de mim para mim”, “sem a menor consideração pelos leitores eventuais”(Peixoto 1940:17).

Snr. Tripa - Recebemos o seu artigo sobre il terzo atto della Divina Comedia. Apezar de interessante, não o publicamos porque o amigo compreenderá que a obra de Dante não é de hoje. Foi publicada a 25 séculos. Portanto ninguém mais deve fazer-lhe a critica atualmente [...].

Passamos agora a responder a sua última carta:

Sabemos perfeitamente que o trabalho de nosso caricaturista não presta, mas que fazer? Não pudemos arranjar outro.

$\mathrm{O}$ amigo sabe que fizemos vantajosas propostas a Tom e Maramao para virem fazer o nosso jornal, á vista do sucesso desses dois artistas geniaes na ultima phase do seu Pasqualino. Tom e Maraméo recusaram altivamente, e nós, com a 
alma cheia de dor, fomos constrangidos a contractar il povero Voltolino que andava se empenhando para trabalhar num semanario como todos sabem.

Publicamos hoje a sua segunda carta do carcamano (d'abax'o Pigues). Fique certo de que conservaremos o incognito.

(O Pirralho, 26 ago. 1911)

Repletos de mistérios e códigos impenetráveis do pequeno mundo da imprensa, o "Sr. Tripa" poderia muito bem ser um dos correspondentes epistolares macarrônicos ${ }^{9}$ d'O Pirralho (1911). Provavelmente o "Sr. Tripa" fazia suas cartas macarrônicas, porém, através da coluna das "Cartas do Abaix'o Pigues" redigidas por Annibale Scipione (Oswald de Andrade) em O Pirralho(1911) descobrimos que o "Tripa" era o editor-chefe do Pasquino Coloniale, em que o caricaturista Voltolino (Lemmo Lemmi), citado nesta "posta" d'O Pirralho, também ilustrava. Logo a alusão pilhérica a Voltolino e ao "Sr. Tripa" articulava os famosos "elogios às avessas", típicos do estilo irreverente desta coluna, colocando ambos na "berlinda" a fim de torná-los mais evidentes. Provavelmente para os leitores de $O$ Pirralho, tanto Voltolino como o "Tripa" eram pessoas bastante conhecidas. Voltolino foi um dos ilustradores do início do século XX que mais colaborou na imprensa paulista ${ }^{10}$.

Além das colunas de "posta restante" serem um lugar nas folhas interessante para desvendarmos personagens desconhecidos que participaram da vida da imprensa paulista, seria importante destacar o papel destas colunas como espaço multiplicador de matérias e colunas que surgiam espalhadas em outros espaços das folhas.

A "posta" nesse sentido reunia temas diversos, aludia a nomes já conhecidos como o do já citado ilustrador Voltolino ou apresentava novos nomes, pseudônimos desconhecidos a princípio que passavam a se tornar mais evidentes à medida que

\footnotetext{
${ }^{9} \mathrm{O}$ macarronismo epistolar fartamente utilizado nas colunas de correspondências era considerado uma "língua estrangulada", representação próxima do que se falava pelas ruas da cidade. O Pirralho foi o semanário humorístico paulistano que mais concentrou correspondências macarrônicas, do italiano, do caipira e até do alemão.

${ }^{10}$ Para ver a grande participação de Voltolino na imprensa paulista, o trabalho mais completo é a pesquisa de Belluzzo (1992).
} 
se repetiam em colunas próprias ou ilustrações já divulgadas previamente nas ambivalentes mensagens desta seção de entrada das folhas.

A mecânica dos semanários através das colunas de "posta restante" foi sem dúvida um subversor de ordens, programado para não obedecer de maneira nenhuma ao registro ordenado dos recebimentos postais. A insubordinação foi a grande organizadora destas colunas que nunca obedeciam a quantidades exatas do número de entradas e nem de saídas. Se havia alguma regra, talvez a única era de multiplicar ou dividir tudo que estava registrado na coluna como suposta entrada. Neste caso de fato, a semelhança era mera aparência, o que valia era a transposição e a equivalência destes mecanismos fixos coordenados na própria produção e distribuição dos jornais. Através das colunas de "postas" a vida noticiosa poderia ser transformada, suspensa, prolongada, duplicada ou mesmo transposta, as cartas eram de fato "sem sel-o"

\section{Logogrifos telegramas: o lugar dos "telegramas" nos semanários de narrativa irreverente}

A idéia de imediaticidade das informações por meio de telegramas expandia o poder de comunicação da imprensa em geral e também transformava a linguagem dos pequenos jornais irreverentes sintonizados com o momento no início do século XX surgindo nos semanários como colunas fixas telegráficas.

Um dos grandes fatores para a expansão da imprensa foi a utilização de mecanismos mais rápidos de captação e transmissão das mensagens. A invenção dos telégrafos no final do século XIX somava-se ao surgimento da imprensa diária e às máquinas de impressão mais modernas.

1896 foi um ano-chave na história da imprensa assim como na divulgação de mensagens via telégrafos. Nesse ano que na Grã-Bretanha foi fundado o jornal com verdadeiras características populares, o Daily Mail de Alfred Harmsworth. Um ano antes Gugliemo Marconi chegou à Grã-Bretanha com um novo equipamento que alterava o funcionamento dos telégrafos a fio, o telégrafo sem fio, e os irmãos Lumiére haviam inventado o cinematógrafo (Bradbury/McFarlene 1999:45).

\footnotetext{
11 "Cartas sem sel-o", subtítulo da coluna de posta restante da revista Cri-Cri (1907).
} 
A princípio o telégrafo sem fio foi considerado apenas um substituto dos telégrafos com fio e não uma forma nova de comunicação e divulgação das mensagens. " [...] na verdade, o fato de as mensagens transmitidas pelo rádio poderem ser captadas por pessoas estranhas parecia mais um retrocesso do que um avanço" (Civita 1985 V.I: 7).

No Brasil, a primeira agência telegráfica ligada à imprensa foi instalada em 1874. A agência telegráfica Reuter-Havas teve sua sucursal no Rio de Janeiro. A partir de então as notícias que chegavam através do correio ou pela imprensa estrangeira, passaram a vir do exterior pelos telégrafos.

No dia $1^{\circ}$ de agosto de 1877 , o jornal $O$ Comércio do Rio de Janeiro já publicava os primeiros telegramas enviados em 30 de julho, registrados em vários horários diferentes. Em 1895 era vez do jornal carioca, A Notícia, também publicar da mensagem captada pelos telégrafos as lutas em Cuba. Os leitores ainda incrédulos com a capacidade de transmissão tão rápida dos acontecimentos chegaram a duvidar das informações publicadas nesse jornal, só vindo a acreditar quando confirmadas pelo jornal O Comércio no outro dia (Sodré 1998:267).

A partir de 1897, com a expansão de serviços dos correios, o volume de tráfego dos telégrafos também começa a aumentar. Porém, como afirmou Maciel (1998:5457) ao aumento dos serviços, a eficácia de recepção e emissão das mensagens não se dava sem que ocorressem inúmeras reclamações dos usuários em relação à morosidade e erros nas mensagens telegráficas. Os problemas se davam pelas constantes interrupções no tráfego e com a mão-de-obra técnica. As propostas de solução passavam pela duplicação das linhas, aquisição de aparelhos mais velozes e o mais complicado, a formação de técnicos mais habilitados.

Entre os vários problemas de adaptação e introdução de aparelhos mais atualizados, como o Baudot, que permitia a transmissão e recepção simultânea das mensagens, os telegrafistas acabavam sendo os principais provocadores de falhas e interrupções do sistema de emissão e recepção das mensagens. Estes, por dominarem precariamente os códigos telegráficos, muito freqüientemente usavam os telégrafos em "conversas" informais em "circuitos de diferentes resistências", o que causava “instabilidades" na qualidade das mensagens (Maciel 1998: 54-57).

Devido ao baixo nível cultural dos técnicos telegrafistas que enviavam as mensagens, as confusões e a má qualidade destas eram públicas e notórias entre os usuários. Paralelo aos limites técnicos e humanos, surgia para a fixação do mecanismo 
dos telégrafos e seu funcionamento, todo um debate sobre a padronização da linguagem telegráfica - "as convenções na linguagem e a redação dos telegramas - se clara ou cifrada" -, a fim de condicionar a telegrafia nacional ao código internacional. O código Morse foi a forma mais popularizada deste alfabeto telegráfico padronizado, no qual a cada combinação de sinais gráficos se representava uma letra do alfabeto oficial. Através do código Morse mandavam-se "mensagens de amor, pêsames ou negócios [...] num mesmo estilo de linguagem lacônica, seca, rápida e econômica", decodificadas depois por teleimpressores ou máquinas de escrever (Maciel 1998:54-57).

A esse ambiente carregado de controvérsias e soluções originadas pela implantação dos telégrafos, somava-se o seu grande poder de atração representado pela imediaticidade das mensagens. A imprensa diária foi uma das primeiras a adotar as mensagens telegráficas como aliadas na recepção e publicação das notícias jornalísticas.

A idéia de imediaticidade das mensagens aliada à presença destas na imprensa diária também incorporava-se às folhas irreverentes de forma bastante singular. Em grande parte refletindo mais uma vez estes curtos-circuitos que mediavam a mecanização dos novos tempos e a forma como estes eram implantados. Para os jornais de narrativa irreverente paulistanos que circularam nos primeiros anos do século XX, a presença de colunas fixas com o título de chamada "Telegramas" foi uma constante.

A fixação das colunas e a disposição das mensagens eram uma alusão clara aos telegramas publicados na grande imprensa. Porém, assim como nas colunas de “ posta restante", o viés irreverente em que a vida noticiosa era abordada por esta pequena imprensa, a fixação dos “Telegramas”, não viria sem um reaproveitamento da própria linguagem telegráfica.

De pontos próximos ou distantes, através dos telégrafos com fio ou sem telégrafo nenhum, as mensagens chegavam à imprensa de narrativa irreverente. Sintonizadas as ondas do momento, os pequenos jornais mostravam as possibilidades de versatilidade dos breves telegramas ao serem retransmitidos nas colunas das folhas.

Mais próximos da cidade, surgiam na coluna "Telegramas" d' O Bolina de 13 de dezembro de 1900 mensagens emolduradas com subtítulos relacionados a fatos diversos ocorridos na circunscrição urbana: "um duelo", "um capoeira”, "uma vingança", "uma demissão", "um empastelamento de jornal”, "um incêndio", "uma tentativa de suicídio", "uma encomenda de Santos" ou mesmo "um escândalo". 
Obedecendo as regras telegráficas, as breves mensagens precisavam o lugar e o dia dos acontecimentos, porém a precisão era apenas aparente. A brevidade e a disposição das colunas, ao serem lidas, davam lugar a pequenos fatos ocorridos entre pessoas conhecidas ou ainda diálogos tramados de uma mensagem telegráfica que lhe era sucessiva.

No telegrama "Demissão", que teve lugar na "Redação do Commercio [grifo meu] no dia 1 (retardado)", uma curta mensagem avisa que "Neves Junior [grifo meu] demitiu-se desta redacção para não levar outra [...]". Já no telegrama sucessivo a este, com o título "Empastelamento", enviado da Repartição Central no mesmo dia 1 (retardado), a mensagem completava de forma engraçada o código cifrado da anterior: "O Chico de Castro prometeu empastelar o Commercio [grifo meu] inclusive o Neves Junior [grifo meu]" (O Bolina, 13 dez. 1900).

Já a coluna "Telegramas" d'O Azeite de $1^{\circ}$ de junho de 1903 , recebidos diretamente dos

"fios da Light and Polvora", mantinha seus temas e lugares ligados a diversos pontos da cidade: ruas e pontos de diversão sucedidos pelo registro do dia da semana em que as mensagens chegaram. Porém, novamente a precisão só durava na definição mais aparente do período da semana e na brevidade da mensagem. Os temas tratados nas mensagens telegráficas eram todos retrabalhados ficcionalmente, buscando, no caso, ter como foco o próprio órgão emissor das mensagens telegráficas. As mensagens com notícias de ruas e lugares da cidade se fechavam todos em torno do semanário $O$ Azeite, que azeitava toda a coluna "Telegramas": "Villa Buarque, 31 - Azeitamento por todas as ruas, janelas, portas, portões, cocheiras, bonds, egrejas, jardins e etc. Em todo lugar é só azeite" (O Azeite, $1^{\circ}$ jun. 1903).

O Athleta de 15 de setembro de 1901 se atrevia a sair um pouco da vida das mensagens enviadas da própria cidade de São Paulo e fazia um giro que partia de pequenos fatos ocorridos com pessoas conhecidas no bairro das Perdizes em São Paulo, para diversificar sua recepção de mensagens telegráficas em outros pontos do Estado: Araras e Ribeirão Preto.

O Mosquito, nos dias 14 e 15 de setembro de 1901, além de se deslocar da área central da cidade de São Paulo e ir comentar fatos diversos ocorridos na Penha e em Cotia, trazia uma outra singularidade que apontava novos caminhos para a lin- 
guagem irreverente e noticiosa. A sucessão dos telegramas que por hábito funcionavam como encadeamento de temas em seqüência assumia com muito mais precisão o tempo, registrando em sua coluna as horas e minutos das mensagens que se seguiam. Na narrativa da pequena imprensa irreverente não bastava mais a imediaticidade, o jogo das palavras lançava nas mensagens telegráficas a composição lúdica entre o tempo e o espaço. As colunas de "Telegramas" passavam a adquirir a precisão dos movimentos em encadeamento:

Penha 10 hs. 35 ms.

O povo está todo espantado de vêr um anjo com azas na torre. Julgam que é o fim do mundo que está próximo.

Penha 11 hs. $36 \mathrm{~ms}$.

Facto verificado. Era uma moça que por causa de ter uma corcunda um pouco extensa o povo pensava que era azas (O Mosquito, 14 e 15 set. 1901).

Já no semanário A Arara de 5 de agosto de 1905, a precisão dos fatos ligava-se aos acontecimentos da semana. Entre Rio e São Paulo surgiam flashes alternados de acontecimentos variados ocorridos nas duas cidades. Dos assuntos políticos, um telegrama do Rio, dia $1^{\circ}$, comentando o fato do padre Valoise "que fôra excomungar o governo do Dr.Tibiriça". Da vida dos divertimentos por telegrama vindo de Santos, do dia $1^{\circ}$, anunciavase que Coquelin, famoso artista francês, fora desafiado pelo Padre Severino para bater-se em duelo. Os motivos do tal duelo escapavam da coluna de "Telegramas" de A Arara para se alojarem de forma "cifrada" na coluna de "divertimentos" ao lado, na qual os comentários críticos sobre os espetáculos da semana nos vários teatros da cidade de São Paulo destacavam a despedida de Coquelin no Teatro Santana:

Foi embora a troupe Coquelin, que trouxe em reboliço durante cinco noites os diletantes e apreciadores de theatro. Apesar das descomposturas do Padre Severino de Rezende e de uns discolos que o acompanharam, porque um tolo acha sempre um outro tolo para acompanhá-lo [...] (A Arara, 5 ago. 1905).

A extrema precisão da imprensa irreverente, sensível aos acontecimentos do momento e multiplicadora em suas colunas das possibilidades temáticas desses eventos também aliava-se de forma bem-sucedida à linguagem das mensagens telegráficas, fazendo com que ambas, por vezes, passassem a compor diálogos diversos 
que poderiam "incorporar" suas próprias matrizes fixas. O final da coluna "Telegramas" de A Arara anunciava mais uma trama lúdica capturada na narrativa irreverente. Quem assinava a coluna era uma paródia a própria sucursal dos telégrafos implantada no Rio de Janeiro em 1877, a pioneira agência de telégrafos ReuterHavas, a "Hovas" de autoria do cronista de plantão d’A Arara .

Já $O$ Garoto, de 6 de janeiro de 1901, semanário burlesco que ia aos limites da linguagem lúdica, brincava com as distâncias transformando a precisão das mensagens e seus locais de origem em transmissões truncadas, ambíguas e extremamente duvidosas.

Do "Interior" chegava uma mensagem inútil de Bananal do dia 5, onde a população estava bestificada, "Nada de novo acontecia”. Mantendo-se no "Interior" vinha duvidosa mensagem da Capital, Rio dia 5, onde sabia-se através de telegrama vindo "de não sei onde", que o vapor que levava o ator Chaby para a Europa havia naufragado. E, por último, uma mensagem em trocadilho de Salto de Itu do dia 5, em que a confusão se dava justamente na brincadeira com o nome truncado da cidade: o Salto de Itu cujo salto do rio Itu fora negociado pela Câmara a um importante sindicato estrangeiro, deixou a população ao mesmo tempo feliz e intrigada: "A população aplaude a idéia, mas achase intrigada por saber como será transportado o Salto.” (O Garoto, 6 jan. 1901).

Do "Exterior", a primeira mensagem duvidosa chegava de Nova York, do dia 4 (retardado), e anunciava a naturalização do Dr. Fernando Albuquerque, capitalista brasileiro nos Estados Unidos, “A população de lá comemorou” (grifo meu). De Paris, do dia 5 vinha a notícia de que a Light and Power, instalada "aqui (grifo meu) no Brasil" seria vendida a um sindicato brasileiro, "em virtude desta noticia os fundos baixaram muito, reinando pânico no mercado do café". De lá ou daqui? (O Garoto, 6 jan. 1901)

O Cara-Dura de 29 de janeiro de 1905 publicava sua coluna de mensagens telegráficas em língua italiana pelo "Sistema Cara Dura”, o qual utilizava a valorização da simultaneidade para fazer ao seu modo a transmissão dos acontecimentos na Europa para os imigrantes italianos de São Paulo e dar sua nota crítica local dos fatos que se sucediam "lá e aqui".

De Roma, do dia 14 "(ore concialiative)", ligava-se em sucessão ao seguinte telegrama também de Roma, 14 "(ora de pentimento e reparazione)", que se deslocava para o grande acontecimento do momento, o conflito russo-japonês em "Porto Arturo" 
em "(ora felici)" para finalmente chegar a São Paulo "(Brasile)" em "ultima ora" e "ultimissima", onde se juntava simultaneamente a crítica aos fatos locais.

Porém os telegramas não se fixavam apenas nas colunas. Na verdade a linguagem das mensagens telegráficas se espalhava pelas várias matérias e ilustrações gráficas das folhas, causando na narrativa da imprensa irreverente efeitos muito próximos da simultaneidade gerada por sua matriz primária. Os mecanismos de transmissão rápida e as mensagens cifradas dos telégrafos provocavam na linguagem da narrativa irreverente uma profusão de cabos, circuitos, códigos cifrados que já sem fios animavam-se nos embates da língua.

No Jagunço do dia 23 de novembro de 1903, uma nota-piada sobre um incêndio num depósito de lixo que ocorrera durante três dias colocava de imediato os dois proprietários ausentes no momento do sinistro, literalmente no local da ocorrência através dos telégrafos sem fios: "Quando se deu o sinistro estavam fora da capital o sr. Paschoal G. e Vicente R. que logo compareceram ao local vindo ambos pelo telegrapho sem fios".

Em A Lua de março de 1910, o telégrafo entrava na matéria através de uma composição com o cinema. Logo no título "Cinema Telegraphico" se dava a breve cena apresentada na matéria que nada mais era do que a discussão enigmática entre dois sujeitos no trem, motivados pela forma como um deles fazia a leitura d'A Lua:

- O sr. está lendo "A Lua”, de cabeça para baixo?

- Orá, vá se catar, seu ignorante! Então pensa que não sei que quem sabe lêr pode ter o jornal em qualquer posição e lel-o de cabeça para baixo, de lado, como quizer?

- Ora, vá para o diabo! Aposto que você é analphabetico!

(A Lua, mar. 1910)

Porém, o desfecho final da forma "correta" de ler o jornal resultava na acusação incorreta de "analfaphabetico" do outro que lia A Lua de cabeça para baixo, talvez extremamente pautada no clima de "comédia ortográfica" que reinava em debate no mundo das letras à época sugerindo para este um grande anedotário. Em linguagem mais cifrada ainda para a imprensa de narrativa irreverente, esse julgamento crítico era apenas circunstancial, pois bastava modificar sua posição e novas possibilidades de transmissão telegráfica surgiriam. 
Da mesma forma que os poderes do telégrafo causavam ruídos nos textos, os desenhos caricaturais também passavam a multiplicar as possibilidades da linguagem mecânica dos telégrafos. No Cri-Cri de 10 de janeiro de 1909 surgia pela pena do caricaturista Yôyô o "Telégrafo sem fios”, um desenho de dois amantes unidos por várias linhas imaginárias.

Mantendo a idéia da sintonia dos telegramas sem fios, em A Lua (1910), uma outra ilustração de Yôyô afinava ainda mais as mensagens telegráficas, ao mostrar uma dama decodificando sem sombra de dúvida os gestos que intrigavam tanto seu pai:

- Que diabo, estará fazendo aquelle rapaz com aquelles gestos, nenê?

- Quem sabe si é mudo, papae! Com os seus botões - Já sei: amanhan, ás 7, á janella.(A Lua, fev. 1910)

A linguagem telegráfica, por sua permanente repetição e diversificação, alfabetizava-se cada vez mais nas folhas, sendo capaz de penetrar no mundo dos jogos de linguagem, território liberto da vida real, em que as palavras cifradas revelavam-se nas dobraduras da língua.

As famosas charadas, cada vez mais presentes nos jornais de narrativa irreverente, também surgiam aliadas aos telegramas em uma de suas formas mais complexas - os logogrifos -, em que a adivinhação está numa palavra prévia, fixa, que em conjunto tem as mesmas letras que aquela combinada de formas diferentes. Com o título de "Logogriphos Telegrammas", um dos colaboradores "12 d'A Lua lançava sua "charada telegráfica" aos leitores do semanário:

"Logogriphos Telegrammas"

Um gatuno roubou nesta cidade

$1,3,4,2,3$

$6,3,11,2,8$

$9,5,11,2$,

7,12,11,2,10.

(A Lua Cheia, fev. 1910)

\footnotetext{
${ }^{12}$ As colaborações na seção de charadas dos semanários normalmente eram feitas por leitores dos semanários.
} 
Talvez fosse possível ler A Lua em posições diferentes, bastava que se compreendessem os vários malabarismos da língua.

\section{Referências bibliográficas}

AGUDO, José. Cartas D’Oeste. São Paulo, Typographia Pensamento, 1914.

BELUZZO, Ana Maria. Voltolino e as Raízes do Modernismo. São Paulo, Marco Zero, 1992.

BRADBURY, Malcom \& MACFARLENE, James (orgs.). Modernismo (guia). São Paulo, Companhia das Letras, 1999.

CIVITA, Victor (coord.). Nosso Século 1900/1910. V.I, São Paulo, Abril Cultural, 1985

DANTAS, Macedo. Cornélio Pires: Criação e Riso. São Paulo, Livraria Duas Cidades, 1976.

GORDINHO,Margarida Cinta et al. Gráfica: Arte e Indústria no Brasil: 180 anos de História. São Paulo, Bandeirante, 1991.

JANOVITCH, Paula. Preso por trocadilho: a imprensa de narrativa irreverente paulistana de 1900 a 1911. São Paulo, tese de doutorado em História Social (mimeo), FFCLH/ USP, 2003

MACIEL, Laura Antunes. A Nação por um Fio: Caminhos, Práticas e Imagens da " Comissão Rondon”. São Paulo, Educ/Fapesp, 1998.

MARTINS,Ana Luiza. Revistas em Revista. São Paulo, Edusp/Imprensa Oficial do Estado de São Paulo/ Fapesp, 2001.

PEIXOTO, Silveira. Falam os escritores. São Paulo, Edições Cultura Brasileira, 1940.

REDONDO,Garcia. Cara Alegre, Porto, Livraria Chardon \&Irmão, 1940.

RIZZINI, Carlos. O Jornalismo antes da Tipografia. São Paulo, Companhia Editora Nacional, 1968.

SALIBA,Elias T. Raizes do Riso. São Paulo, Companhia das Letras, 2002.

SODRÉ, Nelson W. História da Imprensa no Brasil. Rio de Janeiro, Mauad, 1998.

WEBER, Eugen. França Fin-de-Siècle. São Paulo, Companhia das Letras, 1998. 